\title{
Os fastos da ditadura militar, de Eduardo Prado - o brasil de um exilado
}

Regina Zilberman ${ }^{l}$

\begin{abstract}
Fastos da ditadura militar (1890), by Eduardo Prado, contains the five articles originally published between 1889 and 1890 in the Revista de Portugal. In the first two articles, he condemns the republican regime then recently established; in the following three articles, he examines the diplomatic, financial and ethical errors of Deodoro da Fonseca's government. As a conclusion, he warns about the role the Army will play from then on in Brazilian life, assigning to his articles the role of document and diagnosis of a period of national history.
\end{abstract}

Keywords: Eduardo Prado; Fastos da ditadura militar; dictatorship; Republican government.

Resumo: Eduardo Prado reuniu no livro Fastos da ditadura militar, de 1890, os cinco artigos originalmente publicados entre 1889 e 1890 na Revista de Portugal, editada em Paris. Nos dois primeiros artigos, condena o regime republicano então recentemente implantado, nos três seguintes examina os equívocos diplomáticos, financeiros e éticos do governo de Deodoro da Fonseca. Adverte sobre o papel que doravante o exército desempenhará na vida brasileira, atribuindo a seus artigos a função de documento e diagnóstico de um período da história nacional.

Palavras-chave: Eduardo Prado; Fastos da ditadura militar; ditadura; República.

A última vez que vi Eduardo Prado foi na véspera de deixar o Rio de Janeiro para recolher a S. Paulo, dizem que com o gérmen do mal e da morte em si. Naquela ocasião era todo vida e saúde. Quem então me dissesse que ele ia também deixar o mundo, não me causaria espanto, porque a injustiça da natureza acostuma a gente aos seus golpes; mas, é certo que eu buscaria maneira de obter outras horas como aquela, em que me detivesse ao pé dele, para ouvi-lo e admirá-lo.

Machado de Assis (ASSIS, 1959, p. 260)

Os seis artigos que compõem o livro Fastos da ditadura militar no Brasil em Paris, de Eduardo Prado, foram publicados originalmente entre dezembro de 1889 e junho de 1890, na Revista de Portugal, dirigida por Eça de Queirós e sediada em Paris. Na ocasião, o autor não residia na Europa na condição de exilado. Exilado ele esteve depois, ainda que por vontade própria, já que não fora banido do Brasil, mas de onde fora levado a fugir, primeiramente em 1893, após a publicação e confisco de A ilusão americana, depois, entre 1896 e 1897, à época da revolta de Canudos, quando opositores do regime, como era sua

1 Professora Adjunto III do Instituto de Letras da Universidade Federal do Rio Grande do Sul. 
situação, eram acusados de estimular o movimento rebelde de Antônio Conselheiro, com o fito de restaurar a monarquia. ${ }^{2}$

Eduardo era o filho caçula de Veridiana e Martinho Prado, membro de família tradicional do interior paulista e rico proprietário de fazendas de café. A celebridade se transmitiu da mãe, que não hesitou em divorciar-se do marido em 1877, mudar-se para a cidade de São Paulo e manter intensa atividade cultural, aos filhos, Antônio, ministro da Agricultura entre 1885 e 1888 (e pai de Paulo Prado, intelectual modernista), Martinico, político e empresário, e Caio (pai do historiador Caio Prado Junior). A celebridade ainda acompanhou os colegas com os quais Eduardo frequentou a Faculdade de Direito, em São Paulo, já que "de sua turma fizeram parte Afonso Celso, filho do Visconde de Ouro Preto, Assis Brasil, Júlio de Castilhos, Pedro Lessa e Júlio de Mesquita." (LAMPAZZI, 2012, p. 40)

Diplomado em Direito, Eduardo deu início à sua experiência europeia, caracterizada, de uma parte, pelo cosmopolitismo do domicílio em Paris, de outro, pelas viagens a lugares então considerados exóticos. Na capital francesa,

fazia parte do célebre cenáculo de escritores portugueses e brasileiros, que residiam ou circulavam frequentemente pela França, e que era composto pelo próprio Eça de Queiroz, por Oliveira Martins, Ramalho Ortigão, pelo Barão de Rio Branco, e ainda Magalhães de Azevedo, Graça Aranha, José Veríssimo, Domício da Gama e, esporadicamente, por Joaquim Nabuco e Olavo Bilac (Carlos Eduardo Ornelas Berriel, apud LAMPAZZI, 2012, p. 44).

Por outro lado, como que emulando o futuro Fradique Mendes, criação do amigo romancista português, perambulou pela Sicília, Malta e Egito, tema de seu livro Viagens, além de alcançar a América, a Oceania e a Ásia, deslocamentos narrados no segundo volume de Viagens.

Em 1889, Eduardo Prado está estabelecido em Paris, quando ocorre a mudança de regime político no Brasil. Em 15 de novembro, a República fora instaurada por iniciativa de um grupo político e militar encabeçado pelo general Deodoro da Fonseca; em 30 de

2 "Por conta de seu envolvimento político, teve também de fugir duas vezes do Brasil para a Europa, evitando que os excessos republicanos o prendessem. O primeiro episódio se deu com a publicação do A ilusão americana, em 1893, quando a edição foi confiscada e Eduardo achou conveniente ir a Paris, onde ficaria por um bom tempo em companhia de outros refugiados da república brasileira. O segundo se deu no momento de exaltação do governo com a Revolta de Canudos. Os monarquistas foram colocados na clandestinidade, acusados de participação na revolta. Jornalistas foram presos, jornais destruídos e mesmo mortes ocorreram nos excessos partidários do momento. Eduardo, apesar de ser pertencente a uma das famílias mais importantes e ricas do país, achou melhor evitar contratempos e, neste segundo momento, a fuga tomou características singulares, quando disfarçado fugiu de cavalo até a Bahia e de lá tomou um navio para Paris. (LAMPAZZI, 2012, p, p. 84) Em outra versão, a fuga mirabolante ocorreu após o lançamento de $A$ ilusão americana: "Aprendido o livro pela polícia, no dia do lançamento, seguiu-se a ordem de prisão contra o autor, no país já conflagrado pelo movimento de Canudos, pelo levante da esquadra e pela revolução federalista do Rio Grande do Sul, e por isso submetido ao estado de sítio. Ciente dos riscos que isso implicava, partiu a cavalo de sua fazenda no interior de São Paulo e embrenhou-se na aventura que o levou a cruzar desde os sertões de Minas e da Bahia até Salvador, onde logrou tomar o navio que o levou como emigrado a Portugal." (NOGUEIRA, 2003, p. XI) Cândido Motta Filho apresenta as distintas versões desse episódio da vida de Eduardo Prado (MOTTA,1967, p. 249-255). Eduardo Prado narra de modo pitoresco o acontecimento: "É verdade também que, no fim da revolta, entendendo eu que não seria da mínima utilidade para a minha causa ir eu para um cubículo da Correção e julgando que isso me seria particularmente desagradável e incômodo, fui à Bahia, para dali me escapar da América ditatorial, isto é, republicana, para a livre Europa, onde teria, como tive, a liberdade de escrever, que a República então me negava a mim, negava ao Sr. Ferreira de Araújo e a todo o mundo. / Não me resignei, como S. Ex. ${ }^{a}$, à perda dessa liberdade. Fiz essa viagem para readquiri-la. / Confesso que parte da viagem foi feita a cavalo. / Parece que este ponto é particularmente importante para a História." (PRADO, 1959, p. 51) 
novembro, o inconformado intelectual redige o primeiro dos seis artigos publicados na Revista de Portugal, lançados os subsequentes, naquele períódico, entre janeiro e junho de 1890. Logo depois são reunidos no livro Fastos da ditadura militar no Brasil, assinado com um pseudônimo - Frederico de S. Em 1890, registram-se quatro edições da obra, distintas no que diz respeito ao número de páginas (conforme os catálogos das bibliotecas consultadas), mas todas sem indicação de editora, nem do local de impressão. É de supor, pois, que se trata de publicação patrocinada pelo autor, ocorrida talvez em Portugal, como dão a entender os registros constantes no catálogo da British Library. ${ }^{3}$

A circunstância de as impressões de Fastos da ditadura militar no Brasil terem ocorrido provavelmente na Europa não significa que não tivessem circulado no Brasil. De todo modo, em 1891, parece ter havido uma versão nacional, que estaria "aumentada com novos artigos", lançada pela Livraria Americana, da cidade de Pelotas, conforme a referência do catálogo da Biblioteca Brasiliana. ${ }^{4}$ Mais difundida no país foi provavelmente a edição de 1902, produzida pela Escola Tipográfica Salesiana, responsável também pela publicação dos volumes de viagens. Como não se trata propriamente de uma empresa, mas de uma tipografia, pode-se cogitar que esses lançamentos fossem promovidos por familiares de Eduardo Prado, que falecera no ano anterior, ${ }^{5}$ ou por admiradores seus - provavelmente Afonso Celso de Assis Figueiredo, o Visconde de Ouro Preto, o último presidente do Conselho de Ministros do Império. Fastos da ditadura militar no Brasil é ainda objeto de uma quinta edição em 1923, impressa por Magalhães, de São Paulo. Oitenta anos depois, em 2003, o livro foi outra vez publicado, agora pela Martins Fontes, sendo essa talvez a primeira versão comercial da obra.

\section{Os fatos e os Fastos}

O livro abre com uma introdução assinada por Frederico de S., o pseudônimo escolhido pelo autor para representá-lo. Esclarece de imediato que o objetivo, com a reprodução dos artigos publicados primeiramente na Revista de Portugal, era posicionar-se "contra as práticas adotadas pela ditadura militar e republicana no Brasil" (p. XIX). ${ }^{6}$

Esse posicionamento se evidencia em "Os acontecimentos do Brasil", primeiro dos seis artigos, com oito páginas. Anuncia com certo estarrecimento a queda da monarquia ocorrida no Brasil, e as ações subsequentes dos novos detentores do poder, cuja única

3 Cf.http://catalogue.bl.uk/primo_library/libweb/action/display.do?tabs=moreTab\&ct=display\&fn=sear ch\&doc $=$ BLL0 $1003212605 \&$ ind $x=1 \&$ recIds $=$ BLL01003212605\& recIdxs $=0 \&$ elementId $=0$ \& renderM ode $=$ poppedOut $\&$ displayMode $=$ full $\&$ frbrVersion $=\& d s c n t=1 \& \operatorname{scp}$. scps $=$ scope $\% 3 \mathrm{~A} \% 28 \mathrm{BLCONTEN}$ $\mathrm{T} \% 29 \& \mathrm{frbg}=\& \mathrm{tab}=$ local_tab\&dstmp $=1397068951136 \& \mathrm{srt}=$ rank\&mode $=$ Basic \&vl(488279563UI0) $=$ any \&dum $=$ true $\& \mathrm{tb}=\mathrm{t} \& \mathrm{vl}($ freeText $)=$ Fastos $\% 20 \mathrm{da} \% 20 \mathrm{dictadura} \% 20 \mathrm{militar} \% 20 \mathrm{no} \% 20 \mathrm{Brazil} \& \mathrm{vid}=-$ BLVU1\&gathStatIcon=true. Acesso em 7 de abril de 2014.

$4 \mathrm{http}$ ://www.buscaintegrada.usp.br/primo_library/libweb/action/display.do?tabs=detailsTab\&ct=display\&fn $=$ search\&doc $=$ usp_base $01002362908 \&$ indx $=14 \&$ recIds $=$ usp_base $01002362908 \&$ recIdxs $=3 \&$ elementId $=$ $3 \&$ renderMode $=$ poppedOut\&displayMode $=$ full $\&$ frbrVersion $=2 \& \mathrm{dscnt}=0 \& \mathrm{fctN}=$ facet domain $\&$ fromLogi $\mathrm{n}=$ true $\& \mathrm{fctV}=\mathrm{BBM} \& \mathrm{dstmp}=1397410304622 \& \mathrm{vl}($ freeText 0$)=$ Eduardo + Prado $\& v i d=\mathrm{USP} \&$ gathStatIcon=tr ue. Acesso em 12 de abril de 2014.

5 Eduardo Prado pertencera à Academia Brasileira de Letras, e sua vaga foi preenchida por Afonso Arinos, monarquista como ele e autor de Os jagunços e Pelo sertão. Prado havia adquirido, em 1895, O Comércio de São Paulo, que se tornou porta-voz da causa monarquista na capital paulista. Em 1897, à época do conflito de Canudos, Arinos, a convite do proprietário, assumiu a direção daquele jornal. Em 7 de março de 1897, $O$ Comércio foi invadido e destruído (LEONZO, 1987, p. 109), acusado de tomar o partido dos rebeldes.

6 As citações provêm de FREDERICO DE S. (Eduardo Prado). Fastos da ditadura militar no Brasil. São Paulo: Martins Fontes, 2003. São indicadas doravante as páginas onde se encontram. 


\section{Conexão Letras}

providência inovadora, conforme Frederico de S., fora promover a prisão ou o desterro de "quem mostra opinião contrária à do povo, do exército e da marinha." (p. 5, grifos do A.) Uma frase resume a situação vigente: "O Brasil está neste momento sob o regime militar.” (p. 6); logo, não se trata da passagem do sistema monárquico para o republicano, mas a substituição do regime "civil" (segundo o autor, o país vinha sendo governado por um "rei civil") pelo "militar" (p. 6).

$\mathrm{O}$ artigo é curto, e o autor apresenta-se como um cronista, "a quem somente cumpre contar os acontecimentos" (p. 2). Narra-os por meio da transcrição dos telegramas enviados às agências europeias de notícias, mas, ao colá-los em sequência, alcança novo efeito de sentido, desarticulando, com humor irônico, as intenções do emissor brasileiro:

A tropa em estado de revolta. Reina tranquilidade. - O Imperador em Petrópolis. Completa paz. - Foi preso o ministério. População calma. - Foi proclamada a república. Tudo inalterado. - O Imperador preso no seu palácio. Ordem perfeita. - Fica constituído o seguinte governo provisório: Marechal Deodoro da Fonseca, presidente sem pasta; tenente-coronel Benjamin Constant, ministro da guerra; Campos Sales, ministro da justiça; Quintino Bocaiúva, ministro dos negócios estrangeiros; Aristides Lobo, ministro do interior; Rui Barbosa, ministro da Fazenda; chefe de divisão Wandelcock, ministro da marinha; Demétrio Ribeiro, ministro da agricultura, comércio e obras públicas. As províncias aderem. O Senado, o Conselho de Estado, foram abolidos. A Câmara dos Deputados foi dissolvida. Reina sossego. - O Imperador e a família imperial embarcaram para a Europa. - A Bahia não adere ao movimento. Absoluta unanimidade, etc. etc. (p. 2-3).

Ao lado da ironia, o incômodo de Eduardo Prado, para quem o movimento revoltoso nivelou o Brasil às demais nações latino-americanas dos quais nosso país até então se distinguiria. Por isso, afirma no segundo parágrafo do artigo: "a queda da uma monarquia e a consequente e clássica proclamação de uma república não são espetáculo novo para o nosso século.” (p. 1) A seguir, descreve como se dão os golpes de Estado:

A revolta militar do Rio de Janeiro, ampliada, pelo seu resultado, numa revolução; as proclamações; a deposição, a partida do soberano destronado; as mudanças de bandeira, de selos do correio; as prisões, as deportações, os manifestos, até a bênção do arcebispo são episódios obrigatórios desses dramas nos países meridionais, dramas tantas vezes representados e de que a revolução brasileira não é mais do que uma inesperada e (até agora) bem-sucedida reprise. (p. 1, grifo do A.)

Prado poderia estar exagerando, mas traduzia, de certo modo, a percepção dos acontecimentos pelos contemporâneos, a ponto de esses eventos reaparecerem, em chave paródica, mas não menos contudente, em curto episódio de "Recuerdos", capítulo XL de Esaú e Jacó, o romance que Machado de Assis publicou em 1904, mas que se passa no período em que o Brasil transita da monarquia à república:

Foi em Caracas, onde ele servira na qualidade de adido de legação. Estava em casa, de palestra com uma atriz da moda, pessoa chistosa e garrida. De repente, ouviram um clamor grande, vozes tumultuosas, vibrantes, crescentes...

- Que rumor é este, Carmen? perguntou ele entre duas carícias.

- Não se assuste, amigo meu; é o governo que cai.

- Mas eu ouço aclamações...

- Então é o governo que sobe. Não se assuste. Amanhã é tempo de ir cumprimentá-lo. (ASSIS, 1959, p. 159) 
O segundo artigo, de 9 de janeiro de 1890, soma onze páginas e dá continuidade à apresentação dos "acontecimentos do Brasil", de onde se obtêm notícias graças ao "telégrafo submarino" (p. 9). Prado chama a atenção para o fato de que se sabe "do Governo Provisório do Brasil apenas o que esse governo quer que dele se saiba” (p. 9), sublinhando, outra vez com ironia amarga, a dedicação de Rui Barbosa, então ministro das Finanças, à atividade intensa de enviar informações sumárias às nações estrangeiras. De novo Prado destaca a similitude entre o compartamento do governo brasileiro e o das demais repúblicas latino-americanas, e denuncia o amordaçamento da imprensa nacional: "A república, assim, em menos de dois meses, destrói a liberdade de imprensa que o Império garantiu e sustentou durante sessenta anos." (p. 11)

Com a censura à imprensa e a prisão dos opositores, "o Governo Provisório, em matéria de delicadeza e de escrúpulo, se parece com as demais tiranias da América” (p. 12). Identifica a "sede de despotismo" (p. 13) dos governantes, e conclui: "No Brasil a questão hoje não está já posta entre a república e a monarquia. A luta é entre a liberdade e a tirania.” (p. 18).

No último parágrafo, o Autor propõe discutível comparação entre o antigo e o novo regime. Lembra primeiramente que "até há pouco tempo, o Brasil destacava-se entre as nações cristãs e civilizadas por uma anomalia singular e humilhante": a persistência da escravidão entre, segundo ele, "uma pequena parte da população brasileira", vergonha que "os patriotas brasileiros e com eles Dom Pedro II" haviam apagado, de modo que "no Brasil não houve mais senão homens livres" (p. 19). A seguir, assinala a indesejável inversão dessa situação: "A tirania miliar entendeu de outro modo a sua missão; e hoje, se viver sem leis, sempre à mercê do capricho alheio, é viver sem liberdade - pode-se afirmar que, no Brasil, não há senão escravos." (p. 19)

A partir do terceiro artigo, de 15 de fevereiro, o cronista altera o rumo da argumentação. Embora persistam as sucessivas denúncias dos atos arbitrários praticados pelo autodenominado e contraditoriamente permanente Governo Provisório, liderado por Deodoro da Fonseca, que Prado chama de "generalíssimo" e que equipara aos demais "tiranos militares da América Central” (p. 27), o autor começa a abordar questões candentes da política externa do país. Os textos, agora mais extensos, são igualmente mais densos e reflexivos.

Assim o terceiro artigo, de dezoito páginas, enfoca a chamada questão das Missões (ou de Palmas), pendência entre o Brasil e a Argentina pela posse de território situado a oeste de Santa Catarina, reivindicado pelo governo de Buenos Aires. Eduardo Prado denuncia a ambição portenha, que, com a ocupação daquela região, isolaria o Rio Grande do Sul e deixaria o Paraguai à sua mercê. No artigo subsequente, de março de 1990, bem mais longo, com trinta páginas, o autor retoma o assunto, destacando as evidentes vantagens que a Argentina obteria com o tratado entre os dois países e denunciando o posicionamento servil de Quintino Bocaiúva, então encarregado dos Negócios Estrangeiros e incapaz de levar adiante um acordo que beneficiasse sua pátria.

Para comprovar o ponto, o artigo de março amplia as acusações anteriores: a nação fora escravizada, e ocorrera um "enfraquecimento" generalizado em razão da ditadura, já que neste regime "o poder pode tudo e (...) o cidadão nada vale" (p. 40), sendo ele responsável pela "escola do servilismo e do rebaixamento" (p. 43). É esse comportamento que identifica em Bocaiúva por ocasião das negociações relativas às Missões, razão por que examina o tópico de modo mais extenso, valendo-se de mapas e exemplificações.

Conclui o artigo a análise da situação financeira nacional perante os bancos estrangeiros, que, diante da nova situação política brasileira, cancelaram os empréstimos contraídos à época da monarquia: 
Os capitalistas europeus guardarão triste lembrança da revolução do dia 15! As empresas brasileiras, já quase lançadas nos mercados da Europa, ficaram indefinidamente adiadas; os empréstimos de duas províncias [Minas Gerais e Pernambuco], empréstimos resolvidos e aceitos antes da revolução, fracassaram desastrosamente; e o crédito de 150 milhões de francos, aberto em Paris ao governo da monarquia por alguns banqueiros franceses, foi imediatamente cancelado. (p. 62)

Além disso, aponta Eduardo Prado, houve significativa "depreciação dos fundos do governo brasileiro em Londres", conforme demonstra em tabela que acompanha a afirmação. As finanças nacionais são ainda matéria do quinto artigo, de abril de 1890, com trinta páginas. Renovando as acusações ao regime vigente no país - caracterizado pelo "império do arbitrário" (p. 80), pela "imprensa (...) amordaçada" (p. 83) e pelo fato de se tratar de "uma revolução exclusivamente militar", o que "é, para os países civilizados e livres, uma monstruosidade" (p. 83) -, o autor analisa mais uma vez os prejuízos econômicos provocados pela implantação, de modo impositivo, da república. Um quadro detalhado expõe a "depreciação dos fundos brasileiros públicos e particulares em Londres depois do início da ditadura" (p. 85), narrando a seguir as decisões calamitosas de Rui Barbosa relativamente ao capital do então criado Banco dos Estados Unidos do Brasil.

$\mathrm{O}$ artigo final também soma trinta páginas, ao longo das quais Eduardo Prado reitera tópicos até então apontados, qualificando o sistema adotado de "tirania" (p. 104). Se, nos textos anteriores, repudiara a personalidade e as ações de Rui Barbosa e de Quintino Bocaiúva, agora dirige a aversão para Benjamin Constant, a quem acusa de valer-se de sua posição no governo para auferir vantagens pessoais, antes como ministro da Guerra, agora como ministro da Instrução Pública, Correios e Telégrafos:

Trabalhou muito no cargo de ministro da Guerra este felicíssimo militar! Entrou tenente-coronel e, ao cabo de cinco meses, saiu general-de-brigada e grã-cruz de São Bento de Avis. Tudo isso foi conquistado rápida e incruentamente, sem prejuízo dos parentes, que receberam aceleradas promoções e vistosas condecorações. O sr. Benjamin Constant é positivista ortodoxo, mas há meio de acomodar-se sempre a gente com o céu, com o orçamento, e até com São Bento e Augusto Comte. (p. 105).

Ciente de que se trata de um artigo de fechamento, Prado procura relacionar as práticas instaladas pelo novo regime, marcadas, de um lado, pelo arbítrio e a violência, proprias do sistema autoritário inflingido pelo governo, de outro, pela incompetência e pelo oportunismo, de que são exemplos Benjamin Constant e o "banqueiro da ditadura, o sr. Mayrink" (p. 121). A primeira dessas marcas é a imposição de um novo modelo de exercício do poder, assumido pelo exército, que procede de modo ditatorial, logo, sem consulta à nação. $\mathrm{O}$ diagnóstico de Eduardo Prado coincide com um prognóstico digno de menção:

Em todos os países cultos e livres aprende-se nas escolas que todos os poderes são delegações da nação, que o povo é soberano e governa-se a si mesmo por meio de seus representantes livremente eleitos. À nova geração no Brasil, a ditadura está ensinando que o exército e que a armada têm o poder de destruir e de constituir governos, aviltante monstruosidade que envenenará por muitos anos a consciência nacional. (p. 110)

Outras práticas identificadas por Eduardo Prado são: os banimentos: "no Brasil nunca houve banido algum antes dos banidos que o sr. Deodoro sentenciou." (p. 118); a censura aos jornais de oposição; a figura do "criminoso político": "Criminoso político! Expressão 
nova no Brasil, mas da qual se serviam frequentemente Rosas e os seus imitadores nas infelizes tiranias republicano-militares da Hispano-América.” (p. 120). Em nota, complementa: "Segundo os últimos jornais, há em Fernando de Noronha 162 pessoas deportadas pela ditadura." (p. 120. Grifo do Autor).

Nos dois parágrafos finais do derradeiro artigo, Eduardo Prado justifica porque se debruçou sobre o regime recentemente implantado no Brasil. Se ao longo dos textos chamou a atenção para a censura imposta à imprensa nacional, de que estaria livre por escrever desde Paris, o que seria razão suficiente para legitimar seus escritos e a indignação que os acompanha, ao concluí-los lembra o papel que poderão desempenhar no futuro:

O que escrevemos há de ser lido no futuro. Esta Revista figurará sempre nas bibliotecas da literatura portuguesa, e, quando o Brasil tiver voltado à vida normal das nações livres, quem folhear estas páginas há de estimar o escritor que se revoltou contra a ditadura da inconsciência jacobina e soldadesca.

Ninguém duvidará então de que quem escreve estas linhas só atacou os dominadores do Brasil porque, como homem civilizado e do seu século, aborreceu a traição, amou a liberdade e detestou a tirania. (p. 133)

Eduardo Prado não se satisfez com a divulgação de seu pensamento por meio da Revista de Portugal e procurou ampliar sua difusão com o lançamento de várias edições do livro a que atribuiu o título de Fastos da ditadura militar no Brasil, nome que utilizara parcialmente no terceiro artigo, quando, de certo modo, constatara que o regime republicano viera para ficar e que o exército tão cedo não deixaria o governo.

O título adotado remete à obra de Ovídio, cujos Fastos foram dedicados ao imperador Augusto, na tentativa de escapar ao banimento que, contudo, se concretizou. Eduardo Prado não tinha sido banido, mas denunciou vigorosamente os atos de deportação praticados pelo governo provisório que, depois, viriam a se prolongar à época de Floriano Peixoto e que o atingiriam por ocasião do lançamento de $A$ ilusão americana. A premonição, portanto, não era infundada, embora sua vítima não desejasse as graças do regime, mas sua erradicação.

\section{O Brasil de Eduardo Prado}

Estabelecido em Paris, mas com contatos permanentes em Londres, Eduardo Prado não era apenas um ricaço que, indolentemente, usufruía seus rendimentos entre a elite lusobrasileira sediada na Cidade Luz. Nem mesmo Eça de Queiroz, que teria aproveitado traços do rapaz para compor Jacinto de Tormes, o protagonista de $A$ cidade e as serras, apresenta-o como um playboy ocioso, mas como um indivíduo inteligente, embora entendiado, que não encontra sentido em uma existência à primeira vista sem problemas financeiros, até retornar ao lugar de nascimento e redescobrir as origens telúricas portuguesas.

De todo modo, a circunstância de que Eça teve condições de converter o ilustrado brasileiro, dono de prósperas lavouras de café, em um português do Minho, sugere que Prado talvez se mostrasse um desterritorializado, situação, contudo, que possivelmente só se consumou após a proclamação da República, já que o romance apareceu nas livrarias em 1900. Por volta de 1889, Prado tinha uma função específica na Europa, circulando entre as capitais da França e do Reino Unido: era quem cuidava dos negócios internacionais da família Prado, ${ }^{7}$ não apenas produtora, mas também exportadora de café, e não unicamente

7 “Eduardo Prado (...) atuava, quando necessário, junto aos capitalistas ingleses, negociando empréstimos 


\section{Conexão Letras}

ligada aos assuntos da lavoura, mas também acionista da Mogiana e da Companhia Paulista de Estadas de Ferro, cuja presidência foi ocupada por muitos anos por seu irmão, Conselheiro Antônio Prado (FONTANARI, SAES, OLIVEIRA, s. d.; LAMOUNIER, 2009).

Por outro lado, pode-se supor que Eduardo Prado se descobriu um monarquista de quatro costados quando se deparou com as notícias da mudança de regime político no Brasil. Até então tinha escrito livros e textos sobre viagens (o volume dedicado a Sicília, Malta e Egito data de 1886), além de se mostrar comprometido com o catolicismo e a Igreja, de que é exemplo a coletânea, lançada em 1900, comemorativa do terceiro centenário de José de Anchieta.

José Verissimo, na História da literatura brasileira, chama a atenção para o "reacionarismo católico e monárquico" (VERISSIMO, 1963, p. 293) de Eduardo Prado; Cândido Motta Filho observa que "duas coisas o faziam conservador: a religião e a formação brasileira.” (MOTTA, 1967, p. 129) Mário Casasanta complementa: "Eduardo Prado foi ferido (...) no seu ideal político e no seu ideal religioso, porque testemunhava a substituição do Brasil monárquico e católico por uma república anticatólica". (CASASANTA, 1959, p. 9) Esse posicionamento diferencia-o da geração posivista de que foi colega, por exemplo, na Faculdade de Direito, e que predominava entre a juventude nacional, mesmo entre a elite paulista, a quem agradavam alguns princípios republicanos, entre os quais os que requeriam a descentralização da administração política, a ser abrigada pelo sistema federativo, adotado pelos novos dirigentes em 1889. Não por outra razão o Brasil copia a denominação adotada pelos norte-americanos, passando a designar-se Estados Unidos do Brasil, opção que provoca a indignação do autor dos Fastos:

O Brasil, imitando o México, a Venezuela e a Colômbia de outro tempo, também se chama Estados Unidos, como os Estados Unidos por excelência, que, com a arrogância que lhes é própria, não temerão decerto ser confundidos com quaisquer outros Estados Unidos. (p. 4)

Por sua posição de classe e princípios cristãos, Prado não seria um adepto da revolução antimonárquica, ainda que o governo de Pedro II tivesse trombado com os membros da Igreja brasileira, por ocasião da chamada Questão Religiosa, que opôs o imperador às resoluções antimassônicas de D. Vital, bispo de Olinda. Além disso, os civis e militares que acompanharam Deodoro - ou o induziram a isso (GOMES, 2013) - por ocasião da proclamação da República, provinham dos segmentos urbanos e da classe média, com a qual provavelmente o refinado cosmopolita não se identificaria.

Contudo, não era necessário declarar-se monarquista enquanto Pedro II reinava, cabendo apenas aos republicanos a declaração de filiação partidária. Por sua vez, mesmo Eduardo Prado sabia que, pelas vias legais, o Partido Republicano não chegaria ao poder, porque, como ele escreve no primeiro artigo,

destinados, predominantemente, à construção de ferrovias." (LEONZO, 1987, p. 110). "Ao contrário de seus irmãos, que viajavam pouco e com olhos para os negócios, Eduardo Prado viajava bastante, ou por gostos pessoais ou para arregimentar os negócios da família. Seu principal ponto de parada neste sentido era o centro econômico mundial da época, Londres. Data de 1888 o primeiro empréstimo efetuado, junto a banqueiros judeus em Londres, para a província de São Paulo. Fica claro, no entanto, que seus empréstimos oficiais não tinham um caráter mais amplo do que as próprias necessidades da família em relação ao café, e o dinheiro enviado ao Brasil era invariavelmente investido neste setor da economia paulista. / Fundamental, no entanto, foi sua participação como agente da Companhia Paulista de Vias Férreas e Fluviais, que esteve sob a presidência de seu irmão, Antônio Prado, entre 1892 e 1928. Este, sem dúvida nenhuma, foi o fato de maior importância para os negócios da família durante a Primeira República. Foi ele o negociador direto da compra, pela Companhia Paulista, da Rio Claro Railway, que se estenderia pelas propriedades dos Prado, permitindo o acelerado crescimento econômico cafeeiro na região.” (LAMPAZZI, 2012, p. 78-79) 
em todo o país em que houver um partido adverso à forma do governo, partido ardente e exacerbado pela impossibilidade de legalmente realizar a sua ambição, e ao lado desse partido houver um exército tão justamente descontente de si mesmo e de todo o mundo, como o exército brasileiro, o acordo entre estas duas forças será fatal porque é lógico. $\mathrm{O}$ que resulta desse acordo é sempre a mudança do governo; pouco importa que seja Castellar deposto por Pavia, Serrano por Martinez Campos, ou Dom Pedro II destronado pelo general Deodoro. (p. 2)

Desde o início, portanto, fica evidente a relação entre os republicanos e o acesso ao poder por meio de algum tipo de golpe, o que joga o novo governo necessariamente na ilegalidade. O resultado é um Estado fundado na ilegitimidade, que age por meio do despotismo e da tirania, é autoritário e abusa de suas prerrogativas, valendo-se da censura à imprensa, das prisões arbitrárias, das deportações dos adversários, das demissões de funcionários, de - enfim - algum tipo de terrorismo que amedronta e cala os insatisfeitos.

A avaliação de Eduardo Prado inclui um dado importante - ele identifica o papel desempenhado pelo exército. No primeiro artigo, refere-se mais de uma vez ao descontentamento reinante no exército brasileiro, o que faz com que as Forças Armadas, sob o comando de Deodoro da Fonseca, concretizem o que os civis adeptos do regime republicano não tinham alcançado e mudem o modelo político brasileiro. A partir desse ponto, o poder militar passa a constituir uma força com motor próprio, ainda que o governo de Deodoro inclua civis, como Rui Barbosa - um convertido às pressas, segundo Prado - e Quintino Bocaiúva. Mas a figura que sintetiza as lideranças militares é, segundo o autor, Benjamin Constant, um oficial que nunca pegou em armas, indigno de confiança (já que fora professor dos principezinhos brasileiros, herdeiros de Pedro II), incompetente e oportunista, ao se autopromover e buscar emprego para seus familiares em órgãos governamentais.

Além disso, o exército dispõe de seu modo próprio de governar, pois impõe a "ditadura militar", até então desconhecida no Brasil, sendo doravante invariavelmente considerado nos arranjos políticos que sucederam aos primeiros anos da República. É o que testemunha a trajetória brasileira subsequente, seja quando Hermes da Fonseca é eleito presidente em 1910, quando Getúlio Vargas é deposto em 1945, e depois, quando se suicida em 1954, e enfim quando retoma o protagonismo em 1964, em golpe que, completados cinquenta anos neste 2014, permanece como um esqueleto no armário da história nacional.

Ainda que por razões que, no fundo, podem ser acusadas de conservadoras (ou reacionárias, conforme José Veríssimo), Eduardo Prado flagrou o momento de constituição de uma força política enquanto esse processo se formava e foi capaz de formulá-lo em termos de presságio - "À nova geração no Brasil, a ditadura está ensinando que o exército e que a armada têm o poder de destruir e de constituir governos, aviltante monstruosidade que envenenará por muitos anos a consciência nacional" - que infelizmente se materializou, além de permanecer vivo no horizonte, como uma sombra ameaçadora diante da fragilidade de nossas instituições democráticas.

À medida em que, cronologicamente, avançam os artigos, duas outras importantes questões são trazidas para o primeiro plano por Eduardo Prado. A primeira diz respeito à Questão de Palmas ou das Missões.

Ao final do segundo reinado, o mapa brasileiro tinha a seguinte configuração: ${ }^{8}$ 


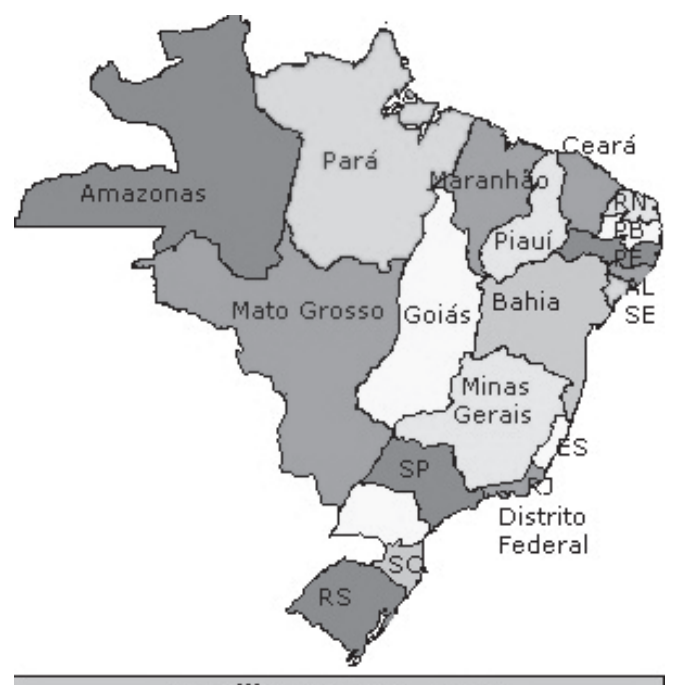

A região a oeste de Santa Catarina, ao sul do Paraná e ao norte do Rio Grande do Sul era objeto de um contencioso entre o Brasil e a República Argentina, que se estendia há algumas décadas. A área, ocupada por colonos brasileiros, era reivindicada pelo governo de Buenos Aires, que pretendia estabelecer as fronteiras pelos rios Chapecó e Chopim. Estrategicamente, representava, para os argentinos, a hipótese de um adentramento do território brasileiro, o isolamento parcial do Rio Grande do Sul e o acesso facilitado ao Paraguai, na altura do rio Iguaçu, como se verifica no mapa: ${ }^{9}$

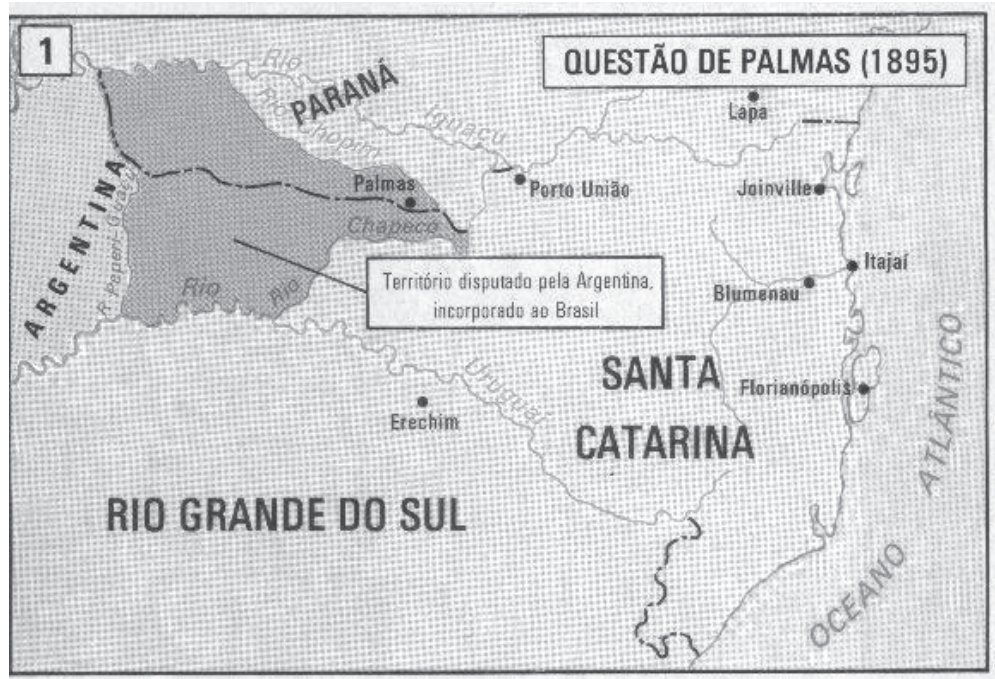

Em várias ocasiões, no século XIX, argentinos e brasileiros se confrontaram militarmente, conflitos que não amenizaram quando a Tríplice Aliança os colocou em oposição ao Paraguai, entre 1864 e 1870. A memória recente desses acontecimentos tornava mais

9 http://fichasmarra.files.wordpress.com/2010/03/7.jpg. Acesso em 09 de abril de 2014. 
premente a busca de solução para a disputa de terras. Por essa razão, uma das primeiras medidas do Governo Provisório foi a tentativa de chegar a um acordo com a Argentina, o que determinou a assinatura do Tratado de Montevidéu, em 25 de janeiro de 1890, em que o Brasil aceitava repartir a área com o adversário diplomático.

Eduardo Prado examina o tópico em dois artigos, no primeiro deles bradando contra a pusilanimidade de Bocaiúva, no segundo detalhando os termos da disputa e reivindicando um posicionamento mais viril por parte do governo brasileiro. Sua voz não deve ter sido a única a ser ouvida, pois, em 1891, o Congresso Nacional rejeitou os termos do Tratado, requerendo arbitragem internacional, atribuída ao então presidente norte-americano Grover Cleveland. José Maria Paranhos, o Visconde de Rio Branco, respondeu pela parte brasileira, tendo provado satisfatoriamente seu ponto e obtendo o laudo favorável do mandatário dos Estados Unidos.

O segundo ponto que Eduardo Prado examina diz respeito às finanças brasileiras, que sofreram alguns baques na esteira do movimento revolucionário republicano. Relata a desconfiança que o novo governo provocou nos banqueiros europeus, que não levaram adiante os empréstimos acordados à época da monarquia. Sublinha a perda do poder de compra da moeda brasileira e a desvalorização das ações das companhias brasileiras, públicas e privadas (entre as quais as de sua família, ainda que ele não aborde a questão desde esse ângulo), que dependiam dos capitais internacionais. E condena a política financeira de Rui Barbosa, "autor de um decreto monstro relativo à organização bancária" (p. 90), de que resulta a criação do Banco dos Estados Unidos do Brasil, cujos capital inicial é, tão logo fundado e por um golpe de caneta, reduzido à metade.

As medidas tomadas por Rui Barbosa, facultando aos bancos a emissão de moeda, lastreada "não em ouro mas em títulos da dívida pública" (FRANCO, LAGO, 2011, p. $11),{ }^{10}$ são tão somente anunciadas por Prado, que testemunhou, e registrou em sua obra, os passos iniciais do que foi, em seguida, vulgarmente conhecido como Encilhamento. Não é Eduardo Prado que dá conta do processo, mas o também monarquista Visconde de Taunay, em $O$ encilhamento, livro de 1893, que reproduz, de modo talvez exagerado, os principais acontecimentos, capazes de possibilitar tanto o acúmulo de fortunas, quanto seu esboroamento em poucos dias. O tópico é igualmente matéria de Machado de Assis, em Esaú e Jacó, que o representa através da personagem Nóbrega, ${ }^{11}$ cujo enriquecimento faculta o acesso às altas rodas cariocas e à proposta de casamento com Flora, a amada dos gêmeos que nomeiam o romance.

O Brasil de Eduardo Prado não estava distante, pois, do Brasil real que outros intelectuais traduziriam mais adiante. Ainda que distante dos acontecimentos, o escritor identificava as questões polêmicas que faziam do país um torvelinho de violência e de irresponsabilidade: perseguiam-se pessoas e dilapidava-se o patrimônio nacional, sem que consequências

10 "O decreto de Rui Barbosa permitindo que "as ações das sociedades anônimas fossem negociadas depois de só $10 \%$ de seu valor ter sido integralizado", e dando "ao banco de Mayrink o direito de emitir 200 mil contos [...] sem a obrigação de resgatar o papel moeda", fazia rebentar a corda na parte mais fraca: no aumento, nunca então sentido, dos gêneros básicos para a manutenção da classe média e baixa." (SOARES, 2011, p. 105)

11 "Poucos meses depois, Nóbrega abandonou as almas a si mesmas, e foi a outros purgatórios, para os quais achou outras opas, outras bacias e finalmente outras notas, esmolas de piedade feliz. Quero dizer que foi a outras carreiras. Com pouco deixou a cidade, e não se sabe se também o país. Quando tornou, trazia alguns pares de contos de réis, que a fortuna dobrou, redobrou e tresdobrou. Enfim, alvoreceu a famosa quadra do "encilhamento". Esta foi a grande opa, a grande bacia, a grande esmola, o grande purgatório. Quem já sabia do andador das almas? A antiga roda perdera-se na obscuridade e na morte. Ele era outro; as feições não eram as mesmas, senão as que o tempo the veio compondo e melhorando.” (ASSIS, 1959, p. 293-294) 
fossem sofridas pelos principais agentes. É o que faz o escritor revestir-se de uma missão salvadora, cuja eficácia o futuro poderia confirmar.

O intuito preservacionista não diz tudo, porém, de Eduardo Prado. Os rumos adotados pela economia brasileira, especialmente seus efeitos no Exterior, atingiam-no diretamente, o que explica não apenas o conhecimento que apresenta no quarto e no quinto artigos, mas também sua indignação, já que afetava seus bolsos e os de sua família. ${ }^{12}$ Essa circunstância não torna a acusação menos importante, e basta lembrar a companhia de Machado de Assis na representação do problema dos investimentos carentes de fundos que os respaldem, para evidenciar que a avaliação do autor era acertada.

O novo regime parece atingir em cheio seus negócios, razão porque, ao contrário de muitos confrades paulistas, posiciona-se imediatamente contra o governo republicano de Deodoro da Fonseca. Eduardo Prado, porém, não foi menos coerente, na sequência de sua vida intelectual, lutando por suas ideias políticas e ideológicas enquanto sua saúde permitiu.

Se ele tinha tudo para ser um letrado caprichoso e entendiado sob os céus de Paris, como talvez o retrate Eça de Queirós, foi efetivamente um combatente enérgico, ainda que suas causas estivessem na contramão da história brasileira. Como ocorreu a outros conservadores dentro e fora de nosso país, foi provavelmente sua concepção avessa ao tipo de progresso almejado por positivistas e militares que facultou uma visão inteiramente desprovida de ilusões do Brasil de seu tempo.

À guisa de conclusão

Os Fastos da ditadura militar no Brasil constituem um acontecimento na vida literária de Eduardo Prado, na medida em que muda a direção de suas preocupações intelectuais e de sua escrita. Considerando a data de publicação, o livro é provavelmente o primeiro manifesto anti-republicano publicado após a instalação do regime presidencial e federativo. Um ano depois, o Visconde de Ouro Preto publica Advento da ditadura militar, impresso em Paris, dando continuidade à bibliografia monarquista de crítica ao sistema político e financeiro vigente, de que faz parte $O$ Encilhamento, do Visconde de Taunay.

O Brasil de Eduardo Prado, nos Fastos, é país dominado pelos militares, que se valem do modelo hierárquico e fortemente corporativo do exército para se manter no poder. Não há governo em que o exército esteja presente que não seja despótico e ditatorial, eis a conclusão do autor, calcado na experiência latino-americana que precede o gesto que levou Deodoro ao controle do Estado. Essa conclusão pode parecer redundante, passados tantos anos de participação das Forças Armadas na política nacional, mas Prado foi capaz de identificá-la no nascedouro. Por mais conservadora que fosse sua visão de mundo, como indica José Veríssimo, não compactuava com o autoritarismo que assinalou a vida política nacional nos primeiros anos da República.

Quando Prado percebeu não ser suficiente acusar a tirania que vigia em sua pátria, deslocou o foco para duas questões que, segundo ele, revelavam a extensão do mal representado pela fundação da República: a ameaça de perda de território, em decorrência dos conchavos dos próceres brasileiros com os países vizinhos, especialmente a Argentina e o Uruguai; a perda de valor da moeda brasileira no mercado financeiro internacional.

Nos dois casos, trata-se de uma preocupação com o Brasil fora das fronteiras nacionais. O Brasil por dentro era governado de modo despótico; o Brasil de fora rendia-se a

12 "O advento da República no Brasil representou para Eduardo Prado, antes de mais nada, uma ameaça à estabilidade econômica de sua família. Assim, justificamos a inserção, nos artigos que integram os Fastos da ditadura militar no Brasil, de textos, fartamente documentados, sobre a depreciação, após o golpe militar de 1889, dos fundos brasileiros públicos e privados no mercado financeiro de Londres." (LEONZO, 1987, p. 110-111) 
exigências estrangeiras. De certo modo, Eduardo Prado percebe uma relação entre os dois processos, indicando que o autoritarismo não necessariamente potencializa o país diante de aliados ou adversários, e até pode enfraquecê-lo.

A maneira com que encara a Questão das Missões foi endossada por seus conterrâneos, e a decisão pela arbitragem internacional garantiu a consolidação das fronteiras brasileiras na região Sul (ainda que não talvez a pacificação interna, já que, vinte anos depois, em local aproximado, deu-se a guerra do Contestado, similar em violência e ideologia à de Canudos). Por outro lado, o modo como se posiciona diante dos capitais estrangeiros sugere que Prado não se mostra tão nacionalista quanto gostaria.

$\mathrm{O}$ autor conhece bem o funcionamento das finanças internacionais, reproduzindo documentação substancial no quinto artigo da Revista de Portugal, porque era o tomador de empréstimos de sua família e, provavelmente, da Província de São Paulo entre os banqueiros londrinos. O período em que acontecem essas transações corresponde ao auge do imperalismo europeu e do colonialismo britânico, que submete os territórios dominados política (como a África) ou economicamente (como a América Latina) a seus interesses, não importando quão predadórios esses poderiam se mostrar. Basta lembrar o episódio do Ultimatum inglês a Portugal, de 11 de janeiro de 1890, logo, contemporâneo aos artigos anti-republicanos de Prado, para verificar o poder exercido pelo Reino Unido sobre regiões que, à primeira vista, nem pertenciam a seus domínios coloniais.

Segundo Hanna Arendt, são os rumos do imperialismo (ao lado do antissemitismo) que conduzirão à emergência e consolidação do totalitarismo que domina a Alemanha nazista e a União Soviética de Stalin (ARENDT, 1989). Assim, ao final do século XIX, desponta um comportamento autoritário, cujas facetas distintas não impedem que os associemos aos movimentos totalitários que alcançam o apogeu por volta da década de 1930 e culminam na segunda guerra, entre 1939 e 1945. E que se se prolonga no estado de exceção identificado e descrito por Giorgio Agamben (AGAMBEN, 2004)

Por mais que Eduardo Prado desejasse, e talvez em decorrência de sua posição de classe e localização geográfica em 1890, ele não poderia vislumbrar que o pior ainda estava por acontecer. Mas, de algum modo, colaborou para a identificação dos perigos da ditadura, o que afiança a validade da maioria de suas teses e a atualidade de sua obra.

\section{Referências}

AGAMBEN, Giorgio. Estado de exceção. Trad. Iraci D. Poleti. 2. ed. São Paulo: Boitempo, 2004.

ARENDT, Hannah. As origens do totalitarismo. Trad. Roberto Raposo. São Paulo: Companhia das Letras, 1989.

ASSIS, Machado de. Eduardo Prado. In: . Crítica literária. São Paulo: Mérito, 1959. ASSIS, Machado de. Esaú e Jacó. São Paulo: Mérito, 1959.

CASASANTA, Mário. Apresentação. In: CASASANTA, Mário (Org.) Eduardo Prado. Trechos escolhidos. Rio de Janeiro: Agir, 1959.

FONTANARI, Rodrigo; SAES, Alexandre Macchione; OLIVEIRA, Paulo Roberto de. Transporte ferroviário e economia regional em São Paulo: comércio de café e gado pela Cia. Mogiana E. F. (1900-1920). In: http://webcache.googleusercontent.com/search?q=cache:9RV Dtflcfc0J:www3.eeg.uminho.pt/aphes33/Comunica\%25E7\%25F5es/FontanariSaesOliveira. pdf $+\& c d=1 \& h l=p t-P T \& c t=c l n k \& g l=b r$. Acesso em 12 de abril de 2014. 


\section{Conexão Letras}

FRANCO, Gustavo H. B.; LAGO, Luiz Aranha Correa do. A economia da República Velha 1889-1930. Rio de Janeiro: Departamento de Economia, PUC-Rio, 2011.

FREDERICO DE S. (Eduardo Prado). Fastos da ditadura militar no Brasil. São Paulo: Martins Fontes, 2003.

GOMES, Laurentino. 1889 - Como um imperador cansado, um marechal vaidoso e um professor injustiçado contribuíram para o fim da Monarquia e a Proclamação da República no Brasil. São Paulo: Globo, 2013.

LAMOUNIER, Maria Lúcia. A Companhia Mogiana de Estradas de Ferro:

investimentos e negócios no novo oeste paulista (São Paulo, 1870-1914). 18 de

dezembro de 2009. In:http://www.economia.unam.mx/cladhe/registro/ponencias/501 abstract.doc. Acesso em 12 de abril de 2014.

LAMPAZZI, Ulisses Pinheiro. Em busca do império: a trajetória intelectual e política de Eduardo Prado. Franca: Universidade Estadual Paulista; Faculdade de Ciências Humanas e Sociais, 2012. Dissertação de mestrado.

LEONZO, Nanci. A historiografia brasileira antirrepublicana: a obra de Eduardo Prado. Revista do Instituto de Estudos Brasileiros, São Paulo, n. 27, 1987.

MOTTA FILHO, Cândido. A vida de Eduardo Prado. Rio de Janeiro: José Olympio, 1967. NOGUEIRA, Octaciano. Apresentação. In: FREDERICO DE S. (Eduardo Prado).

Fastos da ditadura militar no Brasil. São Paulo: Martins Fontes, 2003.

PRADO, Eduardo. Um artigo de Ferreira de Araújo. In: CASASANTA, Mário (Org.)

Eduardo Prado. Trechos escolhidos. Rio de Janeiro: Agir, 1959.

SOARES, Tiago de Castilho. Retórica e política no Congresso Constituinte de 1890-91 Florianópolis: Universidade Federal de Santa Catarina; Instituto de Filosofia e Ciências Humanas, 2011. Tese de doutorado.

VERISSIMO, José. História da literatura brasileira. De Bento Teixeira (1601) a Machado de Assis (1908). 4. ed. Brasília: Universidade de Brasília, 1963. 